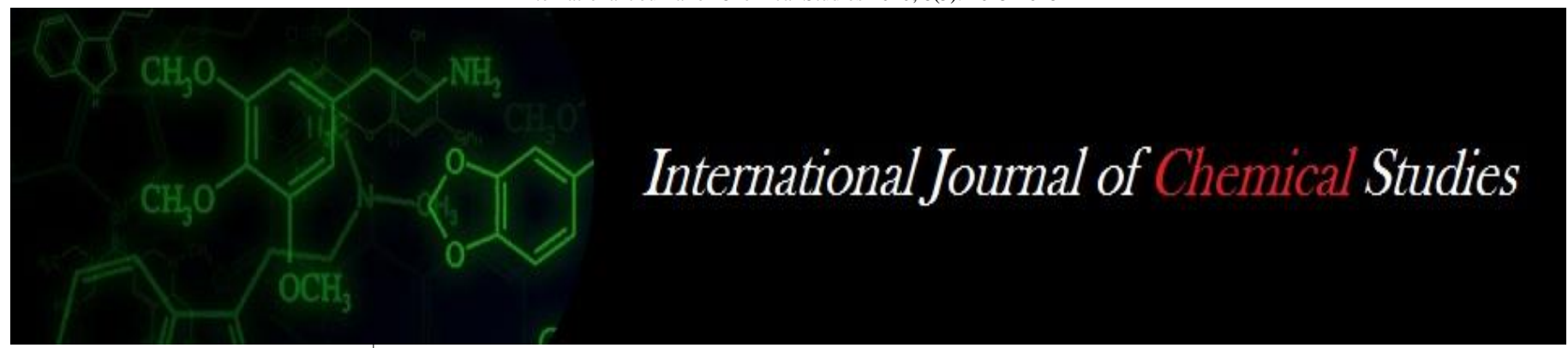

P-ISSN: 2349-8528

E-ISSN: 2321-4902

www.chemijournal.com

IJCS 2020; 8(5): 2615-2618

(C) 2020 IJCS

Received: 25-07-2020

Accepted: 29-08-2020

B Pavan Kumar Naik

Department of Horticulture,

MSSSoA, CUTM,

Paralakhemundi, Odisha, India

\section{Samapika Dalai}

Department of Horticulture,

MSSSoA, CUTM,

Paralakhemundi, Odisha, India

\section{K Mallikarjunarao}

Department of Horticulture,

MSSSoA, CUTM,

Paralakhemundi, Odisha, India

Praveen Kuma

Department of Genetics and

Plant breeding, MSSSoA, CUTM,

Paralakhemundi, Odisha, India

Corresponding Author:

B Pavan Kumar Naik

Department of Horticulture,

MSSSoA, CUTM,

Paralakhemundi, Odisha, India

\section{Heterosis studies in bitter gourd (Momordica charantia $L$.) for yield and yield attributes}

\author{
B Pavan Kumar Naik, Samapika Dalai, K Mallikarjunarao and Praveen \\ Kumar
}

DOI: $\underline{\text { https://doi.org/10.22271/chemi.2020.v8.i5aj.10714 }}$

\begin{abstract}
The experiment was conducted at Bagusala Instructional Farm, M. S. Swaminathan School of Agriculture, Centurion University of Technology and Management, Paralekhemundi, Odisha to study the performance of $10 \mathrm{~F}_{1}$ crosses of bitter gourd obtained from half diallel were studied to investigate the extent of heterosis for yield and its contributing characters. The analysis of variance showing all treatments are significant except days to opening of first female flower. The negative heterosis which is desirable for days to opening of first male flower, number of node bearing first male flower, number of node bearing first female flower in most of the crosses. Significant heterosis was recorded over better parent. The $F_{1}$ crosses Galaxy (Selection 9) x Special Bolder Uccha had identified most important parameter like number of fruits per vine and yield per vine. The crosses Shivam (Selection 12) x Special Bolder Uccha, Galaxy (Selection 9) x Meghdut Korola and Galaxy (Selection 9) x Special Bolder Uccha were noted to be the top performing crosses with respect to earliness and yield parameter.
\end{abstract}

Keywords: Bitter gourd, heterosis, half diallel

\section{Introduction}

Bitter gourd (Momordica charantia L.) is one of the important vegetable crop which belongs to family Cucurbitaceae. Bitterness in bitter gourd is due to the presence of a compound called momordicin. It is highly cross pollinated crop and monoecious in nature. It has several uses, the fruits are used as vegetables in many ways and commonly used in cooked, fried and stuffed form. The fruits are also pickled, canned and dehydrated. The fruits are used as digestive, laxative, antipyretic and reduces blood diseases, rheumatism and asthma (Thangamani and Pugalendhi 2013) ${ }^{[9]}$. It is a rich source of vitamins (A and C) and minerals (iron, calcium and phosphorus). Consumption of fruit juice is very useful for diabetic patients due to its potent oxygen free radical scavenging activity (Sreejayan and Rao 1991). Due to efforts of vegetable breeders, improved varieties and crosses have been developed. The success of any breeding procedure is determined by useful gene combination organized in the form of high heterosis in their crosses. Heterosis in cross pollinated crop has been to offer potentialities for increased yield. Hybrid vigour is substantially increased on crossing genetically diverse inbreds. Though heterosis for yield and yield contributing characters has been reported earlier in bitter gourd by (Singh et al. (2000) ${ }^{[6]}$. Heterosis was calculated as percentage of $F_{1}$ performance in the favourable direction over mid parent and better parent for each trait. The present investigation was therefore, undertaken to obtain information regarding heterosis.

\section{Materials and Methods}

The present investigation entitled "Heterosis studies in bitter gourd (Momordica charantia L.) for yield and yield attributes" was carried out during late kharif season of the year 2019 at Bagusala Instructional Farm, Department of Horticulture, M. S. Swaminathan School of Agriculture, Centurion University, Paralakhemundi, Odisha. The details of experimental techniques, materials and methods adopted for the study are presented in this chapter.

The experimental material comprised of five genetically diverse parents viz., Shivam (Selection 12), Galaxy (Selection 9), West Godavari (short), Special Bolder Uccha and MeghdutKorola were crossed in half diallel design without reciprocals to develop $10 \mathrm{~F}_{1}$ crosses. 
The $10 \mathrm{~F}_{1}$ crosses, 5 parents comprised the material for heterosis and combining studies in bitter gourd which were evaluated in randomized block design with three replication. Observations were recorded in five randomly chosen plants in each replication for vine length $(\mathrm{m})$, days to opening of first female flower, number of node bearing first female flower, fruit length $(\mathrm{cm})$, fruit diameter $(\mathrm{cm})$, fruit weight $(\mathrm{g})$, number of fruits per vine and fruit yield per vine $(\mathrm{kg})$. Heterosis over mid parent and better parent, were calculated following standard statistical procedures by using griffings Model-I and Method-II (Griffings 1956) ${ }^{[2]}$.

\section{Results and Discussion}

The analysis of variance for various yield and yield attributing characters are presented in Table 1. Analysis of variance showed significant differences among the parents for all the traits except days to opening of first female flower under study. This showed the presence of variability in the experimental material for the thirteen characters. The heterosis over mid parent (MP) and better parent (BP) values were estimated for all the thirteen characters among ten crosses are presented in Table 2. For mediating the desirable $\mathrm{F}_{1}$ crosses, negative heterosis values were considered as favourable for traits viz., days to opening of first male flower, days to opening of first female flower, number of node bearing first male flower, number of node bearing first female flower and days to first fruit harvest. While positive heterosis was considered to be desirable for the traits viz., vine length, number of primary branches per vine, fruit diameter $(\mathrm{cm})$, fruit length $(\mathrm{cm})$, fruit weight $(\mathrm{g})$, number of fruits per vine and number of seeds per fruit.

\section{Heterosis for growth parameters}

The cross Special Bolder Uccha x MeghdutKorola (12.83\%) showed the higher significance heterobeltiosis for vine length and the cross West Godavari (Short) $x$ MeghdutKorola $(11.83 \%)$ showed higher significance heterobeltiosis for number of primary branches per vine among the ten crosses. Similar results were reported by Rani et al. (2014) ${ }^{[5]}$ and

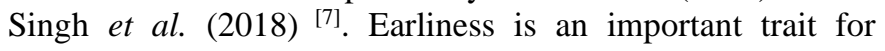
realizing the potential economic yield in as less time as possible which is an important consideration for a vegetable grower in bitter gourd. The flowering time for bitter gourd is measured as the days to opening of first male flower, days to opening of first female flower, number of node bearing first male flower, number of node bearing first female flower. Earliness is a primary goal to indicate the negative heterosis in bitter gourd breeding. In days to opening of first male flower, the cross Shivam (Selection 12) x Special Bolder Uccha (-9.53\%) showed the negative and significant heterobeltiosis. Negative and significant heterobeltiosis was also noticed for days to opening of first female flower for Shivam (Selection 12) x West Godavari (Short) (-6.76\%) appearance in seven crosses.

The cross West Godavari (Short) x Special Bolder Uccha ($30.46 \%$ ) had favourable heterotic values in desirable direction for number of node bearing first male flower. Among the ten crosses, five crosses had significant negative heterosis and number of node bearing first female flower the cross West Godavari (Short) x MeghdutKorola (-26.39) have shown negative and significant heterobeltiosis.

The cross Shivam (Selection 12) x West Godavari (Short) ($5.30 \%$ ) had negative and significant heterobeltiosis values for the days to first fruit harvest for this trait. Similar results were reported by Yadav et al. (2009) ${ }^{[12]}$ and Thangamani et al. (2013) ${ }^{[9]}$.

Heterosis for yield parameters viz., fruit diameter $(\mathrm{cm})$, fruit length $(\mathrm{cm})$, fruit weight $(\mathrm{g})$, number of fruits per vine and fruit yield per vine $(\mathrm{kg})$ are the important towards total yield. The cross West Goavari (Short) x MeghdutKorola had shown the positive and significant heterobeltiosis for fruit diameter. Positive and significant heterobeltiosis has shown in the cross West Godavari (Short) x MeghdutKorola (17.20\%) for fruit length. The cross Galaxy (Selection 9) x MeghdutKorola $(22.42 \%)$ showed higher positive and significant heterobeltiosis for fruit weight. This is in accordance with the earlier reports of Tiwari et al. (2016) [11], Laxuman et al. (2012) ${ }^{[3]}$ and Robindro et al. (2018).

In number of seeds per fruit, the cross Galaxy (Selection 9) $x$ Special Bolder Uccha (17.51\%) has shown positive and significant heterobeltiosis for this trait. Similar results was reported by Rani et al. (2014) ${ }^{[5]}$.

In number of fruits per vine, the cross Galaxy (Selection 9) $\mathrm{x}$ Special Bolder Uccha (24.63\%) had shown the positive and significant heterosis for this trait. Higher estimates of heterobeltiosis were recorded in Galaxy (Selection 9) $x$ Special Bolder Uccha (44.47\%) had registered positive and significant heterosis. This conformity to the earlier findings of Bhatt et al. (2017) [1], Laxuman et al. (2012) [3] and Mallikarjunarao et al. $(2018)^{[4]}$.

Table 1: Analysis of variance for fruit yield and yield contributing characters

\begin{tabular}{|c|c|c|c|c|c|c|c|c|c|c|c|c|c|c|}
\hline $\begin{array}{l}\text { Source of } \\
\text { variation }\end{array}$ & D.f. & $\begin{array}{c}\text { Vine } \\
\text { length } \\
(\mathrm{m})\end{array}$ & $\begin{array}{c}\text { Number } \\
\text { of } \\
\text { primary } \\
\text { branches }\end{array}$ & \begin{tabular}{|c|} 
Days to \\
opening \\
of first \\
male \\
flower \\
\end{tabular} & $\begin{array}{l}\text { Days to } \\
\text { opening } \\
\text { of first } \\
\text { female } \\
\text { flower }\end{array}$ & $\begin{array}{c}\text { Number of } \\
\text { node } \\
\text { bearing } \\
\text { first male } \\
\text { flower } \\
\end{array}$ & $\begin{array}{c}\text { Number of } \\
\text { node bearing } \\
\text { first female } \\
\text { flower }\end{array}$ & $\begin{array}{c}\text { Days to } \\
\text { first } \\
\text { fruit } \\
\text { harvest }\end{array}$ & $\begin{array}{c}\text { Fruit } \\
\text { diameter } \\
(\mathrm{cm})\end{array}$ & $\begin{array}{c}\text { Fruit } \\
\text { length } \\
(\mathrm{cm})\end{array}$ & $\begin{array}{c}\text { Fruit } \\
\text { weight } \\
\text { (g) }\end{array}$ & $\begin{array}{l}\text { Number } \\
\text { of fruits } \\
\text { per vine }\end{array}$ & $\begin{array}{c}\text { Fruit yield } \\
\text { per vine } \\
(\mathrm{kg})\end{array}$ & $\begin{array}{c}\text { Number } \\
\text { of seeds } \\
\text { per fruit }\end{array}$ \\
\hline Replication & 2 & $0.62 * *$ & 10.72 & 3.9 & 5.77 & $6.78 *$ & & 31.41 ** & 0.12 & $6.52 * *$ & $144.48 * *$ & $30.08 * *$ & 28981.34* & 16.67 \\
\hline Treatments & 14 & $0.13 * *$ & $10.69 * *$ & $7.87 * *$ & 5.05 & $4.05 *$ & $9.05 *$ & $10.44 * *$ & $0.26^{* * *}$ & $2.78 * *$ & $32.91 * *$ & $11.79 *$ & 34002.738 ** & $16.26^{* *}$ \\
\hline Error & 28 & 0.04 & 3.45 & 1.36 & 2.56 & & & & 0.038 & 0.26 & 8.57 & 4.35 & 5961.21 & 5.34 \\
\hline Total & 44 & 0.09 & 6.08 & 3.55 & 3.5 & 2.58 & 5.57 & 5.75 & 0.11 & 1.35 & 22.49 & 7.89 & 15929.88 & 9.33 \\
\hline
\end{tabular}

$*$,** Significant at $5 \%$ and $1 \%$ level, respectively

Table 2: Estimation of heterosis over mid parent and better parent for yield and yield attributing characters

\begin{tabular}{|c|c|c|c|c|c|c|c|c|c|c|c|c|}
\hline \multirow[t]{2}{*}{ Crosses } & \multicolumn{2}{|c|}{ Vine length (m) } & \multicolumn{2}{|c|}{\begin{tabular}{|c|} 
Number of \\
primary branches \\
per vine
\end{tabular}} & \multicolumn{2}{|c|}{$\begin{array}{l}\text { Days to opening } \\
\text { of first male } \\
\text { flower }\end{array}$} & \multicolumn{2}{|c|}{$\begin{array}{c}\text { Days to opening } \\
\text { of first female } \\
\text { flower }\end{array}$} & \multicolumn{2}{|c|}{$\begin{array}{c}\text { Number of node } \\
\text { bearing first male } \\
\text { flower }\end{array}$} & \multicolumn{2}{|c|}{$\begin{array}{c}\text { Number of node } \\
\text { bearing first female } \\
\text { flower }\end{array}$} \\
\hline & MP & BP & MP & BP & MP & BP & MP & BP & MP & BP & MP & BP \\
\hline $\begin{array}{c}\text { Shivam (Selection 12) } \mathrm{x} \\
\text { Galaxy (Selection 9) }\end{array}$ & 3.24 & 2.42 & 1.54 & -2.65 & -8.28 & $-8.63^{* *}$ & 1.79 & 1.44 & -22.89 & $-27.27 * *$ & $10.86^{*}$ & 8.98 \\
\hline $\begin{array}{l}\text { Shivam (Selection 12) x } \\
\text { West Godavari (Short) }\end{array}$ & -3.60 & -4.16 & $13.44 * *$ & $10.01 * *$ & 3.54 & 1.33 & -4.98 & $-6.76^{* *}$ & $7.45^{*}$ & 3.79 & -15.69 & $-19.17 *$ \\
\hline
\end{tabular}




\begin{tabular}{|c|c|c|c|c|c|c|c|c|c|c|c|c|}
\hline $\begin{array}{c}\text { Shivam (Selection 12) } \mathrm{x} \\
\text { Special Bolder Uccha }\end{array}$ & $15.30 *$ & $11.07 *$ & $12.61 * *$ & $11.09 * *$ & -8.12 & $-9.53 * *$ & 2.92 & 1.23 & -23.84 & $-25.00 * *$ & $14.69 *$ & $13.87 *$ \\
\hline $\begin{array}{c}\text { Shivam (Selection 12) x } \\
\text { MeghdutKorola }\end{array}$ & -4.26 & -8.41 & $16.65 * *$ & 3.39 & -6.87 & $-7.971 * *$ & -3.48 & $-5.51 * *$ & -6.90 & -10.48 & $-17.54 *$ & $-22.31 * *$ \\
\hline $\begin{array}{l}\text { Galaxy (Selection 9) x } \\
\text { West Godavari (Short) }\end{array}$ & 3.44 & 3.66 & $9.78 *$ & 2.19 & 3.92 & 1.33 & -4.17 & $-6.28 * *$ & $12.91 *$ & $10.16^{*}$ & $-17.01 *$ & $-19.10 *$ \\
\hline $\begin{array}{l}\text { Galaxy (Selection 9) x } \\
\text { Special Bolder Uccha }\end{array}$ & $13.65 *$ & $10.32 * *$ & 3.25 & 0.31 & -6.41 & $-8.18 * *$ & -3.51 & $-5.40 * *$ & -9.38 & -13.28 & -17.89 & $-19.85^{*}$ \\
\hline $\begin{array}{l}\text { Galaxy (Selection 9) x } \\
\text { MeghdutKorola }\end{array}$ & $14.67 *$ & $10.53 * *$ & $13.10 * *$ & -3.37 & -1.01 & -2.54 & -1.58 & $-3.98 * *$ & $13.08 *$ & $14.84 *$ & -15.50 & $-21.67 * *$ \\
\hline $\begin{array}{l}\text { West Godavari (Short) } \mathrm{x} \\
\text { Special Bolder Uccha }\end{array}$ & 4.09 & 0.83 & $15.00 * *$ & $10.06 * *$ & -5.72 & $-6.31 *$ & $5.06^{*}$ & $5.32 *$ & -29.08 & $-30.46 * *$ & $16.33 *$ & $10.76^{*}$ \\
\hline $\begin{array}{c}\text { West Godavari (Short) x } \\
\text { MeghdutKorola }\end{array}$ & 9.36* & 5.20 & $22.73 * *$ & $11.83 * *$ & -3.77 & -4.71 & -3.82 & $-4.06 * *$ & -5.26 & -11.88 & $-18.72^{*}$ & $-26.39 * *$ \\
\hline $\begin{array}{c}\text { Special Bolder Uccha x } \\
\text { MeghdutKorola }\end{array}$ & $13.65 *$ & $12.83 * *$ & $18.37 * *$ & 3.68 & -3.52 & -3.87 & -1.96 & -2.44 & 1.11 & -4.20 & -14.93 & -19.31 \\
\hline
\end{tabular}

$*$, ** Significant at $5 \%$ and $1 \%$ level, respectively.MP $=$ Mid parent and BP = Better parent

Table 2: Cont.,

\begin{tabular}{|c|c|c|c|c|c|c|c|c|c|c|c|c|c|c|}
\hline \multirow[t]{2}{*}{ Crosses } & \multicolumn{2}{|c|}{$\begin{array}{l}\text { Day to first } \\
\text { fruit harvest }\end{array}$} & \multicolumn{2}{|c|}{$\begin{array}{c}\text { Fruit diameter } \\
(\mathrm{cm})\end{array}$} & \multicolumn{2}{|c|}{ Fruit length $(\mathrm{cm})$} & \multicolumn{2}{|c|}{$\begin{array}{c}\text { Fruit weight } \\
(\mathrm{g})\end{array}$} & \multicolumn{2}{|c|}{$\begin{array}{c}\text { Number of } \\
\text { fruits per vine }\end{array}$} & \multicolumn{2}{|c|}{\begin{tabular}{|c|} 
Fruit yield \\
per vine $(\mathrm{kg})$
\end{tabular}} & \multicolumn{2}{|c|}{\begin{tabular}{|c|} 
Number of \\
seeds per fruit
\end{tabular}} \\
\hline & MP & BP & MP & BP & MP & BP & MP & BP & MP & BP & MP & BP & MP & BP \\
\hline $\begin{array}{c}\text { Shivam (Selection 12) x } \\
\text { Galaxy (Selection 9) }\end{array}$ & $4.46^{*}$ & 2.06 & -4.58 & -6.05 & -2.25 & -2.19 & $10.60 *$ & $8.75^{*}$ & $17.86^{*}$ & $15.61 *$ & $17.89 *$ & $\begin{array}{c}14.78 \\
*\end{array}$ & 3.77 & -3.70 \\
\hline $\begin{array}{l}\text { Shivam (Selection 12) x } \\
\text { West Godavari (Short) }\end{array}$ & -3.77 & $-5.30 *$ & $18.01 * *$ & $15.71 * *$ & $19.38 * *$ & $16.44 * *$ & $\begin{array}{c}19.81 * \\
*\end{array}$ & $\left|\begin{array}{c}17.26 * \\
*\end{array}\right|$ & $17.60 *$ & $12.89 *$ & 4.84 & -4.27 & -22.33 & -28.18 \\
\hline $\begin{array}{l}\text { Shivam (Selection 12) } \mathrm{x} \\
\text { Special Bolder Uccha }\end{array}$ & $4.92 *$ & 2.89 & -4.47 & -4.47 & $6.27 *$ & $4.83 *$ & $8.97 *$ & $7.98 *$ & $17.23 *$ & $14.88 *$ & $22.74 *$ & $\begin{array}{c}16.79 \\
*\end{array}$ & -14.07 & -19.07 \\
\hline $\begin{array}{r}\text { Shivam (Sel } \\
\text { Meghdu }\end{array}$ & -1.17 & -1.46 & $6.06 *$ & $5.59 *$ & 1.42 & -3.12 & 1.22 & -4.09 & 15.93 & $14.11 *$ & -1.25 & -5.09 & -11.21 & -12.38 \\
\hline $\begin{array}{l}\text { Galaxy (Se } \\
\text { West Goda }\end{array}$ & -3.62 & -4.31 & $19.93 * *$ & $15.82 * *$ & $18.60 * *$ & $15.61 * *$ & $\begin{array}{c}24.03 * \\
*\end{array}$ & $\begin{array}{c}19.42 * \\
* \\
\end{array}$ & $20.74 * *$ & $18.12 *$ & $\begin{array}{c}38.45^{*} \\
* \\
\end{array}$ & $\begin{array}{c}29.60 \\
* *\end{array}$ & -4.07 & -4.44 \\
\hline $\begin{array}{l}\text { Galaxy (Selectior } \\
\text { Special Bolder U }\end{array}$ & -4.85 & -5.20 & -2.90 & -4.39 & -2.05 & -3.44 & $\begin{array}{c}17.66^{*} \\
*\end{array}$ & $\begin{array}{c}16.76^{*} \\
*\end{array}$ & $29.61 * *$ & $\begin{array}{c}24.63 * \\
*\end{array}$ & $\begin{array}{c}47.93^{*} \\
*\end{array}$ & $\begin{array}{c}44.47 \\
* * \\
\end{array}$ & $19.36^{*}$ & $\begin{array}{c}17.51^{*} \\
*\end{array}$ \\
\hline $\begin{array}{r}\text { Galaxy (Select } \\
\text { MeghdutK }\end{array}$ & -1.92 & -4.44 & $15.81 *$ & $14.53 *$ & $18.07 * *$ & $12.72 * *$ & $\begin{array}{c}27.13 * \\
*\end{array}$ & $\begin{array}{c}22.42 * \\
*\end{array}$ & $19.49 *$ & $19.06^{*}$ & $\begin{array}{c}42.99 * \\
*\end{array}$ & $\begin{array}{c}41.10 \\
* * \\
\end{array}$ & $17.80^{*}$ & $\begin{array}{c}10.70 * \\
*\end{array}$ \\
\hline $\begin{array}{c}\text { West Godavari (Short) } \mathrm{x} \\
\text { Special Bolder Uccha }\end{array}$ & -1.10 & -1.46 & -1.85 & -3.77 & $15.81^{* *}$ & $14.50 *$ & 1.88 & -1.18 & $17.21 *$ & $10.35^{*}$ & $21.68 *$ & $\begin{array}{c}16.50 \\
* \\
\end{array}$ & 1.18 & -0.77 \\
\hline $\begin{array}{c}\text { West Godavari (Short) x } \\
\text { MeghdutKorola }\end{array}$ & -1.37 & -3.22 & $19.67 *$ & $16.82 * *$ & $19.75 * *$ & $17.20 * *$ & $\begin{array}{c}23.13 * \\
*\end{array}$ & $\begin{array}{c}14.32 * \\
*\end{array}$ & $24.52 * *$ & $\begin{array}{c}21.38 * \\
*\end{array}$ & $\begin{array}{c}48.19 * \\
*\end{array}$ & $\begin{array}{c}40.46 \\
* * \\
\end{array}$ & $24.32 * *$ & $\begin{array}{c}16.41 * \\
*\end{array}$ \\
\hline $\begin{array}{c}\text { Special Bolder Uccha x } \\
\text { MeghdutKorola }\end{array}$ & -1.32 & -3.51 & $7.39 *$ & $6.92 *$ & -3.50 & -6.59 & $9.76^{*}$ & 4.91 & $13.51 *$ & 9.53 & $27.47 *$ & $\begin{array}{c}26.13 \\
*\end{array}$ & 3.58 & -1.20 \\
\hline
\end{tabular}

*, ** Significant at $5 \%$ and $1 \%$ level, respectively. MP = Mid parent and BP = Better parent

\section{Conclusion}

From the present study suggest that the crosses like earliness and higher yield parameters to accomplish higher gains in the $F_{1}$ crosses through heterosis breeding. The cross Galaxy (Selection 9) x Special Bolder Uccha had identified the most important parameter like number of fruits per vine and yield per vine. The crosses Shivam (Selection 12) x Special Bolder Uccha, Galaxy (Selection 9) x MeghdutKorola and Galaxy (Selection 9) x Special Bolder Uccha were noted to be the top performing crosses for earliness and yield parameters since they has shown significant heterosis values. These crosses could be better utilized for the improvement of the characters concerned and intermating among superior segregant resulting from these heterotic crosses, is likely to throw desirable progenies in the subsequent later generations.

\section{Reference}

1. Bhatt L, Singh SP, Soni AK, Samota MK. Studies on heterosis in bitter gourd (Momordica charantia L.). International Journal of Current Microbiology and Applied Science 2017;6(7):4069-4077.

2. Griffing B. Concept of general and specific combining ability in relation to diallel crossing system, Australian Journal of Biological Sciences 1956;9:463-493.
3. Laxuman Patil SA, Salimath PM, Dharmatti PR, Byadgi AS, Nirmalayenagi. Heterosis and combining ability analysis for productivity traits in bitter gourd (Momordica charantia L.). Karnataka Journal of Agriculture Science 2012;25(1):9-13.

4. Mallikarjunarao K, Das AK, Nandi A, Baisakh B, Sahu GS, Tripathy P. Evaluation of parents and hybrids for yield and quality characters in bitter gourd (Momordica charantia L.). International Journal of current microbiology and applied sciences 2018;7(8):1082-1092.

5. Radha Rani K, Surender Raju CH, Ravinder Reddy K. A study on heterosis for yield and earliness in bitter gourd. Indian Journal of Science Research and Technology 2014;2(3):89-97.

6. Singh AK, Pandey UB, Singh M. Studies on heterosis in bitter gourd (Momordica chrantia L.). Vegetable Science 2000;27(2):158-161.

7. Singh PK, Singh VB, Adarsh A, Bisht A, Singh Y. Combining ability analysis in sponge gourd for earliness and yield. Journal of Pharmacognosy and Phytochemistry 2018;7(2):3344-3353.

8. Singh PR, Chandankarak Mohapatra PP, Kumar BA, Hazra P. Manifestation of heterosis in bitter gourd. 
International Journal of Current Microbiology and Applied Science 2018;7(10):1376-1385.

9. Thangamani C, Pugalendhi L. Development of heterotic hybrids in bitter gourd (Momordica charantia L.) for earliness, high yield and quality traits, Asian Journal of Horticulture 2013;8(1):195-201.

10. Thangamani C, Pugalendhi L, Sumathi T, Kavitha C, Rajashree V. Estimation of combining ability and heterosis for yield and quality characters in bitter gourd (Momordica charantia L.). Electronic Journal of Plant Breeding 2011;2(1):62-66.

11. Tiwari NK, Singh VB, Srivastava RK, Pandey AK, Dubey SK. Heterosis a breeding approach: for eaarliness in yield and yield contributing traits of bitter gourd (Momordica charantia L.). Research Environmental Life Science 2016;9(6):725-727.

12. Yadav M, Chaudhary R, Singh DB. Heterosis in bitter gourd (Momordica charantia L.). Journal of Horticulture Science 2009;4(2):170-173. 